\title{
ANALISIS MODEL BISNIS PT. PAHALA BAHARI NUSANTARA DENGAN MENGGUNAKAN PENDEKATAN MODEL BISNIS KANVAS
}

\section{The Analysis of Business Model at PT. Pahala Bahari Nusantara using The Business Model Canvas}

\author{
Oleh: \\ Gun Gumelar Somantri ${ }^{1^{*}}$, Arif Satria ${ }^{2}$, Budhi Hascaryo Iskandar ${ }^{3}$ \\ ${ }^{1}$ Mahasiswa program Studi Magister Manajemen \\ ${ }^{2}$ Staf Pengajar Program Studi Megister Manajemen \\ ${ }^{3}$ Staf Pengajar Program Studi Teknologi Perikanan Laut \\ *Korespondensi: gungumelars91@gmail.com
}

\begin{abstract}
ABSTRAK
Model Bisnis Kanvas (BMC) membantu perusahaan menciptakan model bisnis berdasarkan sembilan blok. Penelitian ini bertujuan menganalisa desain pengembangan model bisnis industri tuna di PT. Pahala Bahari Nusantara (PBN). Metode yang digunakan adalah analisis deskriptif dengan BMC, Metode Delphi, SWOT, dan Blue Ocean Strategy. Pemetaan model bisnis PBN memperlihatkan costumer segment, value proposition, channels, revenue streams, key resources, key activities, key partnership, dan cost structure. Analisis lingkungan eksternal dengan Metode Delphi menunjukkan nilai kekuatan pasar $25,76 \%$, kekuatan industri $24,82 \%$, tren kunci $24,21 \%$ dan kekuatan ekonomi makro 25,21\%. Lingkungan internal yang mempengaruhi model bisnis PBN dipengaruhi oleh produk, infrastructure management, customer interface, dan financial aspect. Berdasarkan hasil evaluasi SWOT, elemen dengan kekuatan tertinggi adalah key partnership dan terendah adalah customer relationship. Probabilitas tertinggi adalah customer segment dan terendah adalah key resource. Ancaman tertinggi adalah value proposition dan terendah adalah customer relationship. Berdasarkan hasil identifikasi sembilan elemen tersebut maka pola model bisnis yang digunakan PBN termasuk dalam pola model bisnis unbundling (terurai) dengan mengintegrasikan bisnis tiga inti yaitu, hubungan pelanggan, inovasi produk, dan insfrastruktur. Elemen yang harus dikembangkan berdasarkan pendekatan Blue Ocean Strategy adalah elemen value proposition. Perusahaan harus bisa menciptakan nilai baru bagi pelanggan.
\end{abstract}

Kata kunci: BMC, pengembangan bisnis, tuna.

\begin{abstract}
Business Model Canvas (BMC) helps companies to create business models based on nine block. This study aims to analyze the design of tuna industry business model in PT. Pahala Bahari Nusantara $(P B N)$.The method used is descriptive analysis with BMC, Delphi Method, SWOT, and Blue Ocean Strategy. The mapping of PBN business model shows costumer segment, value proposition, channels, customer relationship, revenue streams, key resources, key activities, key partnerships, and cost structure.External environment analysis with Delphi Method shows the value of market strength $25,76 \%$, industrial strength $24.82 \%$, key trends $24.21 \%$ and macro-economic strength 25.21\%.Internal environment is influenced by product, infrastructure management, customer interface, and financial aspect. Based on SWOT evaluation, element with the highest strength is the key partnership and the lowest is the customer relationship. The highest probability is customer segment and the lowest is key resource. The highest threat is the value proposition and the lowest is the customer relationship. The pattern of business model used by PBN is unbundling that integrating three core business such as customer relationship, product innovation, and infrastructure. Elements
\end{abstract}


that must be developed based on the Blue Ocean Strategy is value proposition. Companies must be able to create new value for customers.

Keywords: BMC, business development, tuna.

\section{PENDAHULUAN}

Berdasarkan data organisasi pangan dan pertanian dunia, FAO (2014), Indonesia menempati peringkat urutan ke-4 pada tahun 2007 untuk produksi perikanan tangkap kemudian meningkat ke urutan ke-2 di tahun 2012. Keadaan tersebut semestinya menjadikan sektor perikanan menjadi sektor yang potensial di Indonesia. Potensi kelautan perikanan tangkap berdasarkan data BAPPENAS tahun 2016 mencapai 6,5 juta ton pertahun, dan angka tersebut merupakan jumlah tangkapan yang diperbolehkan oleh negara. Kajian FAO dalam laporan bertajuk "2016: The State of World Fisheries and Aquaculture" menggambarkan tren kenaikan konsumsi perikanan.

Peningkatan konsumsi ikan di dunia yang semakin meningkat setiap tahunnya merupakan peluang tersendiri bagi pelaku industri perikanan, dan peluang ini harus dimanfaatkan dengan baik oleh para pelaku pasar domestik. Industri perikanan Indonesia berkembang sesuai dengan kemajuan perikanan global yang mengarah pada sasaran mencapai efisiensi usaha yang optimal. Perdagangan bebas yang terjadi saat ini membuat tingkat persaingan semakin ketat baik lingkup lokal, regional, maupun internasional. Produsen dituntut untuk menghasilkan produk yang baik dari kualitas maupun kuantitas.

Perubahan lingkungan bisnis yang dinamis seperti yang sedang terjadi saat ini menjadikan peran strategi dari sebuah manajemen perusahaan sangat penting. Keberhasilan suatu perusahaan dalam bersaing sangat ditunjang oleh kemampuan untuk mengantisipasi perubahan yang terjadi di lingkungan internal maupun eksternal perusahaan, serta kemampuan untuk bereaksi lebih cepat dibandingkan dengan para pesaing.

PT. Pahala Bahari Nusantara merupakan salah satu perusahaan perikanan swasta yang bergerak di bidang ekspor Indonesia. Ekspor yang dilakukan oleh perusahaan ini merupakan ekspor ikan tuna, tongkol dan cakalang, perusahaan ini sudah ada sejak tahun 2009. Menurut Giesen et.al. (2007), cara terbaik yang dilakukan CEO dalam mengatasi perubahan besar-besaran di berbagai industri adalah dengan cara fokus pada inovasi model bisnis sebagai jalan untuk memenangkan daya saing dan pertumbuhan perusahaan. Menurut Slávik (2014), konsep bisnis model yang paling kompleks adalah bisnis model kanvas dari Osterwelder dan Pigneur. Bisnis model ini menggambarkan tidak hanya ekonomi dan bisnis proses, tetapi bagaimana menciptakan nilai perusahaan. Keuntungan lain dari konsep bisnis model kanvas adalah terskema dan memiliki visualisasi yang universal, serta dapat menjelaskan proses hubungan dari sembilan blok di dalamnya. Dengan kondisi bisnis perikanan saat ini PT. Pahala Bahari Nusantara perlu menyesuaikan model bisnis saat ini dengan menggunakan pendekatan model bisnis kanvas. Setiap organisasi yang ingin terus dapat bertahan akan dituntut untuk melakukan antisipasi terhadap perubahan lingkungan yang pasti terjadi, selain itu juga dituntut untuk memikirkan rencana dari organisasi tersebut ke depannya.

Berdasarkan pemaparan di atas, perlu dilakukan suatu kajian untuk mendapatkan model bisnis yang tepat bagi PT. Pahala Bahari Nusantara maka penelitian ini bertujuan untuk mengidentifikasi model bisnis saat ini dijalankan perusahaan dengan BMC, faktor eksternal dan internal apa saja yang mempengaruhi Model Bisnis Kanvas dan menyusun BMC perusahaan di masa depan.

\section{METODE PENELITIAN}

Penelitian ini dilakukan di PT. Pahala Bahari Nusantara yang berlokasi di Kawasan Karyadeka Panca Murni kav B3, Gemalapik Cikarang Selatan, Cikarang Selatan 17550. Penelitian dilakukan pada 
bulan Januari - Maret 2017. Jenis data yang digunakan dalam penelitian ini berupa data kualitatif dan kuantitatif. Data kualitatif berupa pernyataan yang diperoleh melalui wawancara yang meliputi penjabaran visi, misi dan tujuan perusahaan untuk menentukan sasaran strategi. Sedangkan data kuantitatif berupa data yang dinyatakan dalam angka-angka, yaitu data responden untuk pembobotan sasaran strategis. Pengambilan contoh responden dilakukan secara purposive yang terdiri dari tim manajemen PBN, praktisi dan kalangan akademisi (peneliti/ pengamat/ konsultan).

Sumber data primer yang digunakan dalam penelitian ini diperoleh melalui depth interview kepada responden di internal perusahaan, yaitu dari unsur manajemen beberapa informasi yang diperlukan antara lain; pertama informasi yang dibutuhkan dalam mengidentifikasi sembilan elemen BMC seperti sumber daya kunci, segmen yang dibidik, pemasaran, struktur biaya, proporsi nilai, aktivitas kunci, promosi, dll. Kedua informasi faktor internal dan eksternal perusahaan menggunakan metode Delphi, evaluasi 9 elemen model bisnis menggunakan SWOT sebagai dasar dalam pembuatan model bisnis perbaikan, kemudian membuat desain pengembangan berdasarkan perspektif Blue Ocean Strategy (Kim dan Mauborgne 2005).

Data sekunder diperoleh dengan mengakses informasi/data dari instansi seperti studi literatur. Informasi yang diambil di antaranya; kondisi geografis dan jumlah pengusaha loin, jumlah penduduk dan kondisi sosial ekonomi masyarakat tujuan ekspor. Sumber institusi ialah Kementerian Perikanan dan Kelautan, peneliti lingkup tuna, Badan Pusat Statistik serta sumber lain yang relevan seperti jurnal ilmiah, buku, laporan data internal perusahaan, dan working paper.

\section{HASIL}

\section{Sejarah PT. Pahala Bahari Nusantara}

PT. Pahala Bahari Nusantara merupakan anak perusahaan dari group PT. Pahala yang bergerak di sektor bisnis perikanan. PT. Pahala Bahari Nusantara mulai beroperasi pada tahun 2009, dan berdirinya perusahaan ini diprakarsai oleh Bapak Agus Rosli Rosna. PT. Pahala Bahari Nusantara berkantor pusat di Pinangsia II No. 8, Jakarta Barat 1110, sedangkan pabrik produksinya berada di Kawasan Industri Karyadeka Panca Murni, kav. B3, Cikarang 17550 - Indonesia.

Perusahaan ini didirikan atas dasar latar belakang bahwa Indonesia merupakan salah satu negara yang memiliki sumberdaya perikanan terbesar di dunia, selain itu juga melihat trend serta analisis market yang ada saat itu. Maka, akhirnya didirikanlah perusahaan sektor bisnis perikanan yang merupakan pemasok bahan baku untuk industri perikanan (produsen ikan kaleng). Hingga saat ini perusahaan mampu memenuhi permintaan produksi dan distribusinya dengan pasar seluruh dunia. Oleh karena itu PBN merasa optimis akan prospek sebagai perusahaan yang kompetitif pasar lokal maupun global.

Visi : Menjadi perusahaan perikanan yang diandalkan dan terpercaya dalam ramah dunia, tanpa mengesampingkan prioritas ramah lingkungan dan keberlanjutan sumberdaya. Misi : Menghasilkan produk berkualitas tinggi dengan harga yang tetap kompetitif. Dengan kontinuitas pasokan dan kualitas yang konsisten, meningkatkan hubungan bisnis jangka panjang dan kemitraan di pasar global, serta memberikan penghargaan terbaik untuk mitra bisnis untuk pemasok dan pembeli, sebagai kunci untuk perkembangan dan kesuksesan perusahaan.

Visi dan misi yang demikian maka tantangan ke depan bagi perusahaan ini bukan hanya meningkatkan kapasitas, tetapi juga tetap memprioritaskan perikanan berberlanjutan menjadi sebuah keharusan dengan berbagai kebijakan pemerintah (kementerian) dan kebijakan negara yang menjadi tujuan ekspor namun terkadang cepat berubah. Hal ini memberikan dampak yang tidak sedikit bagi perusahaan dalam menjalankan bisnis yang dilakukan PT. Pahala Bahari Nusantara. 


\section{Kegiatan Bisnis}

Bisnis yang dijalankan PT. Pahala Bahari Nusantara sampai saat ini sudah berjalan hampir 8 tahun, di mulai tahun 2009. Pada awal pembentukannya sampai sekarang perusahaan bergerak sebagai penyuplai bahan baku untuk industri-industri pengalengan di Indonesia, dengan dasar pada saat bahwa Indonesia mempunyai sumberdaya perikanan itu menurut data salah satu yang terbesar di dunia. Kegiatan tersebut hanya berjalan setengah tahun namun setelah berjalan perusahaan melihat peluang besarnya market dan tren ekspor tuna kemudian perusahaan membuat pabrik PBN yang lalu menyasar target pasar ekspor. Saat ini cakupan pasar PBN di antaranya Asia, Eropa, Timur Tengah dan negara-negara di benua Amerika. Pada tahun 2010 dan 2011 PBN menunjukan trend yang baik dalam perkembangannya. Pertumbuhannya pertahun mencapai $10 \%$.

Tahun 2012-2014 merupakan masa dimana industri perikanan berkembang dan maju seiring dengan ketersediaan bahan baku yang memadai. Pertumbuhan industri perikanan khususnya di PT. Pahala Bahari Nusantara mencapai 20\%-25\% setiap tahun dari 2012-2014. Melihat trend positif selama 3 tahun ke belakang, maka manajemen PT. Pahala Bahari Nusantara memutuskan untuk melakukan ekspansi. Pada tahun 2014, PT. Pahala Bahari Nusantara mengembangkan kegiatan industri dengan menambah kapasitas produksi sebesar 100\% dari kapasitas yang tersedia. Pada tahun 2015, faktor eksternal dengan adanya berbagai regulasi baru yang diterapkan terutama berhubungan dengan industri penangkapan ikan menyebabkan suplai bahan baku menjadi berkurang. Namun dengan adanya kemampuan untuk bertahan terhadap kompetisi dan ketersediaan stok yang masih cukup, produksi masih dapat ditingkatkan hanya menjadi kisaran 10\%, sehingga memberi dampak target peningkatan produksi sebesar 30\% manjadi tidak tercapai. Faktor utamanya adalah suplai bahan baku. Tahun 2016, kondisi masih tetap sama dan dengan adanya berbagai regulasi yang belum berubah bahkan penambahan regulasi-regulasi baru, seperti contohnya tentang larangan pengoperasian kapal asing berdasarkan Undang-undang, produksi menjadi semakin sulit dan pertumbuhannya hanya sekitar 5\% dibanding tahun 2015. Trend penurunan produksi terjadi mulai tahun 2015 ke 2016 yang mempengaruhi ialah peraturan pemerintah yang sedang diberlakukan. Di tahun 2017 diharapkan faktor eksternal lebih mendukung sehingga kapasitas produksi menjadi lebih meningkat.

\section{Bahan Baku}

Bahan baku yang digunakan yaitu yellowfin tuna (Thunnus albacares), albacore tuna (Thunnus alalunga), big eye tuna (Thunnus obesus), cakalang (Katsuwonus pelamis) ataupun sesuai permintaan pelanggan. Tuna loin beku merupakan daging ikan tuna yang paling tebal dan mengalami pembekuan mencapai suhu pusat $-18^{\circ} \mathrm{C}$. PT. Pahala Bahari Nusantara mempunyai rata-rata kapasitas produksi tuna loin beku 100-120 ton/hari.

\section{Produk}

Produk-produk yang dihasilkan oleh PT. Pahala Bahari Nusantara sebagai berikut:

Pre-Cooked Tuna Loin: Pree-cooked tuna loin beku adalah suatu produk olahan dengan bahan baku ikan tuna segar yang mengalami perlakuan sebagai berikut: sortasi, pemotongan kepala, sirip dan ekor, pencucian, dimasak, pembuatan loin, pembuangan daging gelap, pembuangan kulit dan perapihan, pembekuan dengan atau tanpa penggelasan, pengepakan dan penyimpanan beku. Penyusutaan berat rata-rata sebesar 65\% sebagai pengontrolan penyusutan bobot.

Pre-Cook Tuna Flakes. Proses pembuatan loin tuna menghasilkan serpihan-serpihan daging tuna yang masih sangat berkualitas sehingga masih menjadi produk unggulan. Apabila mendapat pesanan produk ini dapat diproses sesuai dengan permintaan konsumen.

Whole Tuna: Tuna segar dalam keadaan utuh yang sudah disiangi dan telah diperiksa mutunya kemudian disimpan pada pallet gantung dengan keadaan terbalik dalam suhu $0^{\circ} \mathrm{C}$ paling lama 1 hari 
sejak ikan ditangkap. Ikan tuna yang digunakan untuk produk ini dari berbagai macam jenis tuna, Skipjack tuna dan yellowfin tuna merupakan jenis yang paling banyak dipesan dalam bentuk produk ini.

Fish meal: Tepung ikan merupakan produk samping pengolahan ikan berkadar air rendah yang diperoleh dari kegiatan produksi perusahaan. Produk yang kaya dengan protein dan mineral ini digunakan sebagai bahan baku pakan ternak. PBN mengolah sisa-sisa hasil sampingan menjadi produk ini dan dalam mengolahnya terpisah dari jalur produksi tuna loin. Bahan baku yang digunakan yaitu yellowfin tuna (Thunnus albacares), albacore tuna (Thunnus alalunga), big eye tuna (Thunnus obesus), cakalang (Katsuwonus pelamis) ataupun sesuai permintaan pelanggan. Tuna loin beku merupakan daging ikan tuna yang paling tebal dan mengalami pembekuan mencapai suhu pusat $-18^{\circ} \mathrm{C}$. PT. Pahala Bahari Nusantara mempunyai rata-rata kapasitas produksi tuna loin beku 100-120 ton/hari.

\section{Sarana Produksi}

Menurut PT. Pahala Bahari Nusantara, kapasitas produksi perusahaan mencapai 100-120 ton bahan baku/hari dengan tingkat randemen $65 \%$. Bahan baku yang digunakan dalam kegiatan produksi adalah berbagai jenis ikan tuna, cakalang, dan sesuai permintaan pelanggan yang diperoleh dari multi supplier. Melalui rangkaian proses kerja yang diperlukan guna menghasilkan produk kelautan yang berkualitas tinggi sesuai dengan standar internasional HACCP (Hazard Analysis Critical Control Point), yang dikenal sebagai standar penanganan secara profesional, dimulai dari produk kelautan di kapal sampai akhir produksi. PT. Pahala Bahari Nusantara memiliki peralatan produksi dan manufaktur yang sesuai dengan Standar Nasional Indonesia. Menempati area produksi hampir mencapai 2 hektar dengan mesin yang terstandar termasuk 4 unit air blast freezer dengan kapasitas 40 ton dan 4 unit dilengkapi dengan cold storage di area pabrik dengan kapasitas 100-120 ton/hari. Selain itu memiliki armada mobil pengangkut yang dilengkapi dengan cold storage. Perlengkapan terbaru dengan sistem air ozone dan pendingin yang mampu menghasilkan air dengan temprature $+5^{\circ} \mathrm{C}$. Proses tersebut menjamin temperatur kesterilan air. Hal ini dilakukan guna meningkatkan produktivitas dan produk yang berkualitas.

\section{PEMBAHASAN}

\section{Identifikasi BMC PT. Pahala Bahari Nusantara}

Tahapan dalam mengidentifikasi elemen-elemen model bisnis kanvas melibatkan pihak internal dari PBN yang terdiri dari manajer produksi, Spv.Production planning inventory control, HRD, Finance, dan pemasaran. Ke enam responden ini memiliki kapabilitas dalam memberikan informasi yang relevan terkait data yang dibutuhkan untuk mengidentifikasi masing-masing elemen BMC. Pihak-pihak yang disebutkan merupakan representatif dari perusahaan yang turut serta dalam perumusan model bisnis yang dijalankan saat ini. Berikut hasil identifikasi ke sembilan elemen BMC pada PBN yang sedang dijalankan saat ini:

Hasil pemetaan BMC memperlihatkan terdapat beberapa faktor yang berbeda pada elemen model bisnis dalam (Gambar 1). Penjelasan masing-masing elemen Gambar 1 sebagai berikut :

- Customer Segments (CS). CS produk utama (whole tuna, pre-cooked loin tuna, dan pre-cooked tuna flakes) ialah produsen tuna kaleng di Mexico, Portugal, Italy, Jepang, Spanyol, dan Thailand. CS produk sampingan (fish meal) produsen pakan ternak di Banten, dan Jawa Barat. Berdasarkan uraian dapat disimpulkan bahwa bisnis yang dijalankan perusahaan saat ini bersifat Business to Business dan memiliki target melayani pasar spesifik dan terspesialisasi (pasar ceruk). Menurut Ostelwelder dan Pigneur pasar ini proporsi nilai, saluran distribusi, dan hubungan pelanggan dibuat khusus untuk kebutuhan spesifik ceruk pasar. 
- Value Propositions (VP). PBN memberikan VP berupa kualitas produk, harga produk, kontinuitas pasokan produk, dan berbagai sertifikasi menjamin produk dan membangun kepercayaan pelanggan terhadap produk yang dimiliki seperti:

1. Sertifikasi Hazard Analysis Critical Control Point (HACCP), merupakan suatu sistem yang mengakui bahwa sistem dan prosedur bisnis makanan telah dikembangkan, didokumentasikan dan diterapkan sesuai dengan HACCP. HACCP pada dasarnya merupakan alat untuk membantu mengidentifikasi dan mengendalikan bahaya keamanan pangan yang mungkin terjadi dalam bisnis makanan.

2. Sertifikat Halal, merupakan suatu fatwa tertulis dari Majelis Ulama Indonesia (MUI) yang menyatakan kehalalan suatu produk sesuai dengan syari'at Islam.

3. Sertifikat ISO 22000, merupakan standar sistem manajemen keamanan pangan global untuk seluruh rantai pasokan makanan. Standar ini berfokus pada pemastian rantai pasok, apakah prinsip-prinsip sistem manajemen telah diterapkan dan sesuai dengan prinsip-prinsip HACCP dari Codex Alimentarius.

4. Dolphin safe certificate adalah sertifikat yang dikeluarkan oleh pihak EII (Earth Island Institute) untuk melindungi ikan lumba-lumba.

5. Sertifikat keterlacakan, kesetaraan, dan keberlanjutan dari Kementerian Kelautan Perikanan

6. Sertifikat kelayakan pengolahan yang dikeluarkan oleh Dirjen Penguatan Daya Saing Produk Kelautan KKP.

- Channels (Ch). Channels yang dibagi menjadi 2 cara. Pertama secara langsung menggunakan tenaga penjual, dan penjualan web. Keduanya secara tidak langsung menggunakan media massa.

- Customer Relationships (CR). CR yang dilakukan bersifat personal assistance (bantuan personal) pada pelanggan produk utama maupun sampingan. PBN juga melakukan CR yang bersifat communities untuk membantu dan memfasilitasi terjalinnya hubungan saling menguntungkan antara pelanggan dengan komunitas.

- Revenue Streams (RS). RS atau aliran pendapatan PBN berasal dari penjualan produk-produk yang dihasilkan perusahaaan. Produk tersebut dibagi menjadi dua produk utama (whole tuna, pre-cooked loin tuna, dan pre-cooked tuna flakes) dan produk sampingan (fish meal).

- Key Activities (KA). KA PBN dikelompokkan menjadi 5, yakni kemitraan, produksi, pemasaran, pelayanan dan audit.

- Key Resources (KR). Key resources PBN dikelompokkan pertama, sumber daya fisik berupa bahan baku, fasilitas produksi dan teknologi, kedua, sumber daya manusia berjumlah 1.063 pegawai tetap dan tidak tetap dan sumber daya intelektual.

- Key Partnerships (KP). Key partnertships merupakan mitra kerja PBN terdiri dari pemasok bahan baku ikan tuna, pemasok bahan bahan lain dan penyedia cold storage.

- Cost Structures (CS). Cost structure model bisnis PBN terdiri dari biaya operasional, biaya pemasaran, dan biaya CSR. 


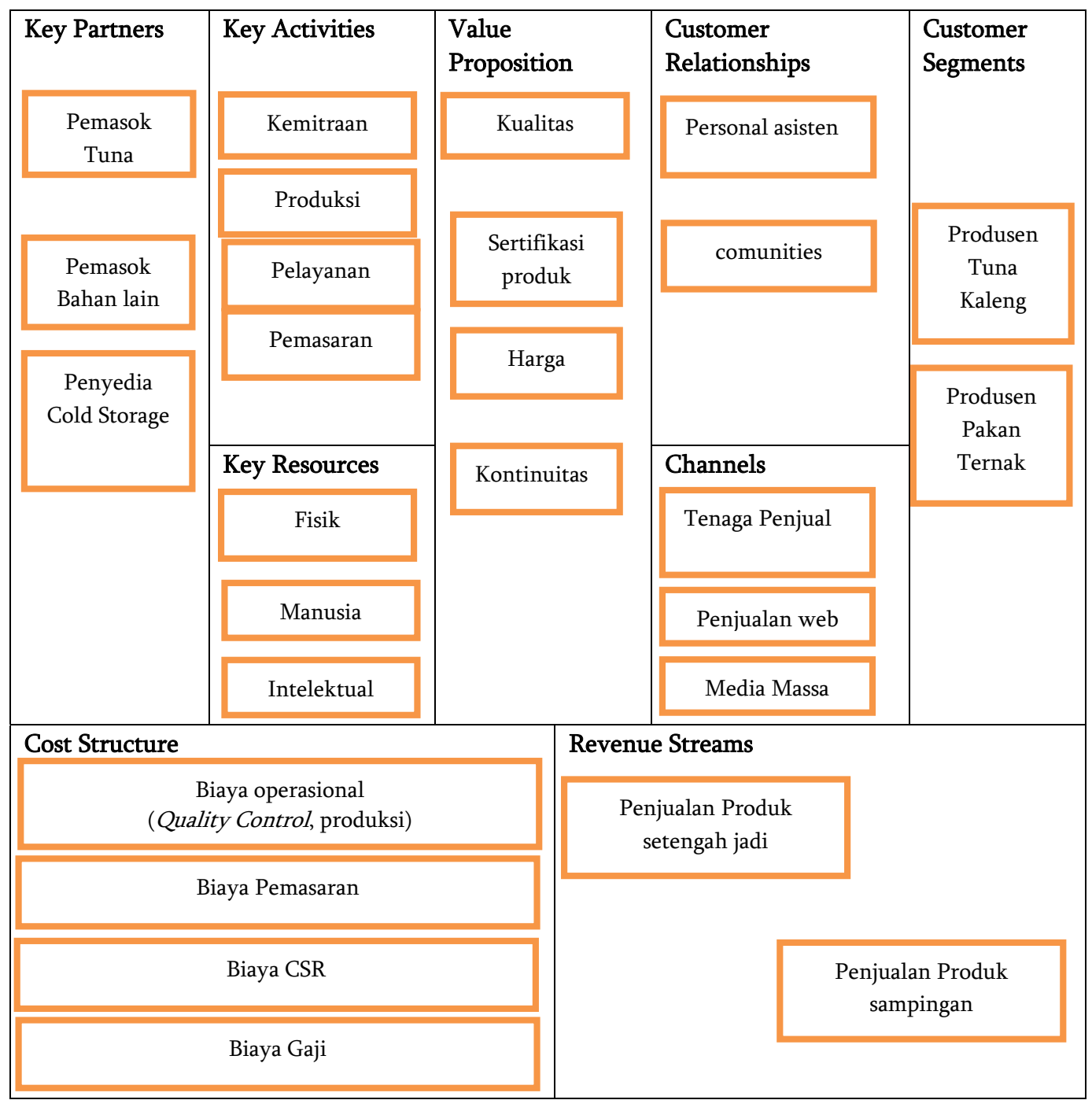

Gambar 1 Pemetaan model bisnis canvas PBN

\section{Pola Model Bisnis PT. Pahala Bahari Nusantara}

Pemetaan yang dilakukan sebelumnya dihasilkan bahwa pola model bisnis adalah unbundling (terurai), dimana perusahaan mengintegrasikan 3 jenis bisnis yang secara fundamental berbeda, yaitu hubungan pelanggan, inovasi produk dan bisnis infrastruktur.

Perusahaan saat ini menunjukan fokusnya pada manajemen infrastruktur dan manajemen hubungan pelanggan, sedangkan untuk inovasi masih menunjukan kurang. Inovasi produk membutuhkan sumber daya manusia yang berbakat dan kreatif agar perusahaan dapat terus melakukan terobosan pasar. Sehingga perusahaan belum bisa dikatakan fokus terhadap inovasi produk dikarenakan bisnis ini yang menjadi kunci adalah skala ekonomi. Pada bisnis manajemen hubungan pelanggan cukup menjadi fokus dikarenakan berorientasi pada pelayanan yang baik selain untuk mempertahankan pelanggan tapi juga untuk mendapatkan pangsa pasar yang lebih besar. perusahaan dengan model unbundling sebaiknya memisahkan ketiga bisnisnya dan hanya fokus pada salah satu dari ketiganya secara internal seperti yang dikatakan Hagel dan Singer pada tahun 1999. Setiap jenis bisnis didorong oleh faktor-faktor yang berbeda, konflik satu sama lain atau tarik menarik kepentingan yang tidak diinginkan dalam satu organisasi yang sama. 


\section{Analisis Lingkungan Internal MBG}

Analisis lingkungan internal dilakukan pada 4 aspek, yakni product, customer interface, infrastructure management dan financial aspect (Osterwalder dan Pigneur 2015). Analisis ini berdasarkan penilaian top management internal perusahaan. Hasil yang diperoleh menunjukan:

- Produk : 26,22\% dengan nilai faktor kualitas, bahan baku, proses produksi dan SDM sebagai faktor yang sangat penting.

- Customer Interface : 25,13\% yakni terdapat 3 faktor yang memengaruhi customer interface PBN, yakni jarak, kedekatan personal dan informasi media. Jarak merupakan faktor yang dinilai sangat penting karena berpengaruh terhadap cara perusahaan untuk memberikan pelayanan.

- Infrastructure Management : 25,68\% dengan faktor terpenting dalam infrastructure management adalah sumber daya manusia (karyawan). Hal-hal yang memengaruhi SDM adalah keterampilan, jumlah.

- Financial Aspect : 22,96\% faktor terpenting dalam aspek finansial adalah harga jual produk. Hal ini dikarenakan penjualan produk merupakan sumber utama aliran uang.

\section{Analisis Lingkungan Eksternal PBN}

Analisis ini dilakukan dengan Metode Delphi. Hasil analisis menunjukkan nilai kekuatan pasar $25,76 \%$, kekuatan industri 24,82\%, tren kunci $24,21 \%$ dan kekuatan ekonomi makro 25,21\%. Kekuatan pasar sangat dipengaruhi oleh kebutuhan dan permintaan, isu-isu pasar, biaya perpindahan dan daya pikat pendapatan. Kekuatan industri sangat dipengaruhi oleh kegiatan pemasok dan pelaku rantai nilai, pesaing dan pemain baru. Tren kunci sangat dipengaruhi oleh perkembangan tren masyarakat dan budaya. Kekuatan ekonomi makro dipengaruhi oleh kondisi pasar grobal dan infrastruktur ekonomi.

\section{Evaluasi Model Bisnis}

Evaluasi 9 elemen model bisnis dilakukan dengan analisis SWOT. Analisis ini mengacu pada pemikiran bagaimana memaksimalkan kekuatan (strengths) dan peluang (opportunities) serta secara beriringan meminimalkan kelemahan (weakness) dan ancaman (threats) (Rangkuti 2004). Evaluasi dilakukan dengan cara pembobotan masing-masing elemen dan menginterpretasikan hasilnya dengan aplikasi Tolo Branca V3.3 untuk melihat kondisi setiap elemen (berbahaya, waspada atau kuat). Hasil evaluasi yang diperoleh seperti terlihat pada Gambar 2.

\section{Desain Pengembangan Model Bisnis}

Setiap elemen BMC dapat menjadi titik awal pengembangan model bisnis baru (Amanullah et al. 2015). Pada penelitian ini desain pengembangan model bisnis dilakukan dengan memadukan BMC dan BOS yang ditekankan pada 4 pertanyaan kunci tentang logika strategi pada model bisnis yang ada. Empat pertanyaan kunci tersebut (mengeliminasi, mengurangi, meningkatkan, menciptakan) diberikan pada semua elemen sisi kanan BMC yang mewakili penciptaan nilai dan sisi kiri yang mewakili biaya. Logika berfikir ini dilakukan untuk menyeimbangkan peningkatan nilai dan pengurangan biaya dalam menciptakan dan menangkap peluang sehingga terjadi tarik-menarik pada setiap elemen. Kombinasi tersebut memungkinkan diperoleh strategi pengembangan yang lebih dari satu atau sesuai dengan banyaknya elemen yang ingin dikembangkan. Untuk itu diperlukan kriteria pemilihan elemen yang akan dikembangkan. Kriteria yang digunakan adalah 1) keselarasan dengan arah pengembangan perusahaan, 2) hasil evaluasi elemen model bisnis, 3) hasil analisis lingkungan internal dan eksternal perusahaan serta 4) pola model bisnis yang ada saat ini. Berdasarkan kriteria tesebut maka dipilih elemen value proposition untuk dikembangkan karena dirasa mewakili 4 kriteria. 


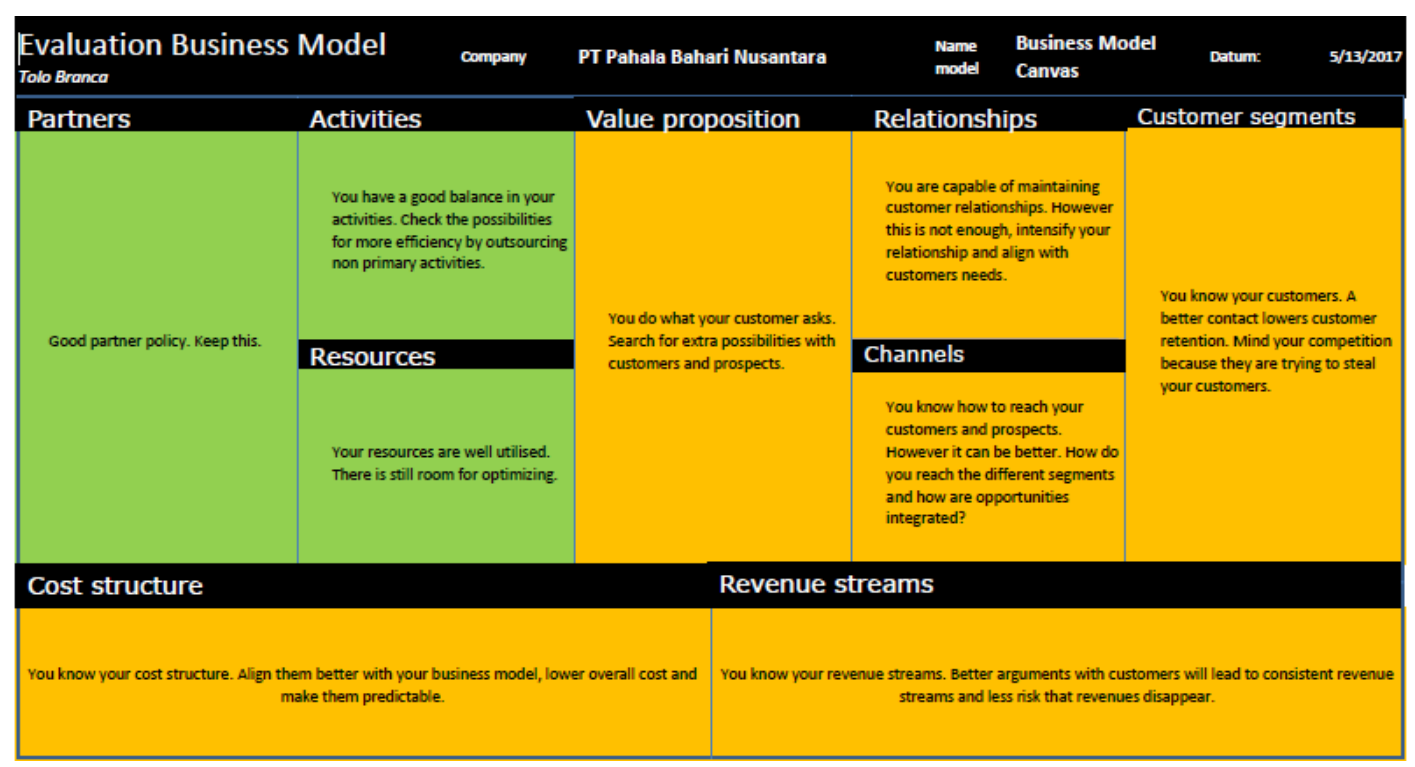

Gambar 2 Penilaian SWOT 9 elemen model bisnis PBN dengan interpretasi Tolo Branca versi 3.3

\section{Pengembangan Model Bisnis}

Berdasarkan hasil evaluasi Tolo branca, elemen Value proposition berada pada kondisi waspada (kuning). Pemilihan elemen ini untuk titik dikembangkan diharapkan selain meningkatkan kondisinya jadi lebih kuat atau bahkan menjadikan BMC perusahaan sesuai dengan keadaan ke depan terlebih lagi arah pengembangan perusahaan yakni menjadi perusahaan perikanan yang diandalkan dan terpercaya dalam ranah dunia, tanpa mengesampingkan prioritas ramah lingkungan dan keberlanjutan sumberdaya. Hasil yang diperoleh dalam wawancara perusahaan akan menambah aktivitasnya yakni “Canning” menciptakan tuna kaleng siap konsumsi. Rencana ini masih dianggap masuk akal dalam 5 tahun ke depan dengan dorongan para pelanggan yang saat ini untuk membuat produk jadi (end customer) mereka di Indonesia. Tahap awal dalam pembuatan tersebut dengan mengerjakan brand produk pelanggan yang ada. Hasil ini sejalan dengan apa yang disarankan oleh evaluasi tolobranca yakni mencari peluang dengan tambahan pelanggan yang memiliki prospek yang baik. Selain itu perusahaan mendapat dorongan dari pelanggan untuk menciptakan produknya langsung di PBN. 


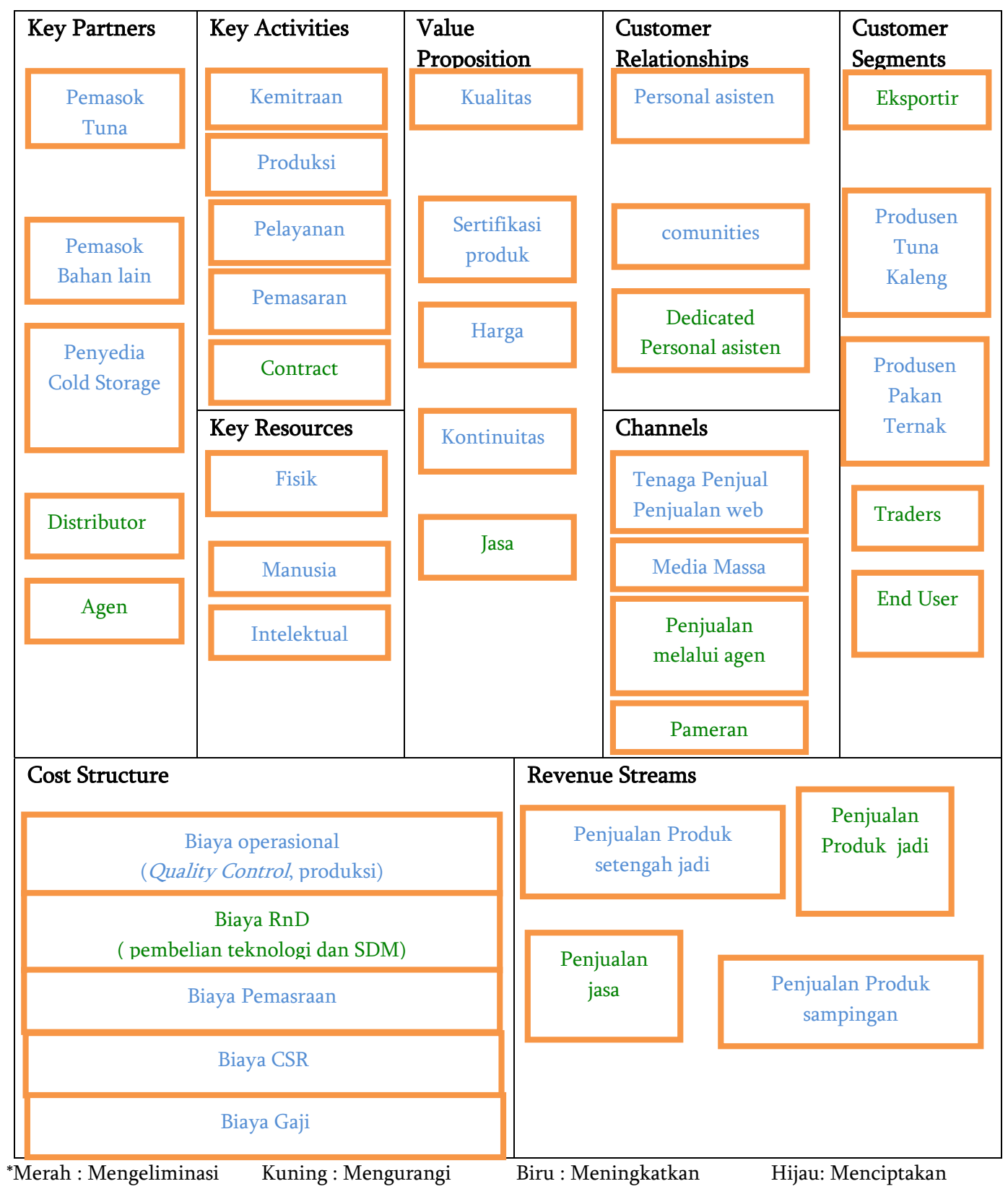

Gambar 3 Pengembangan Model Bisnis

\section{KESIMPULAN DAN SARAN}

\section{Kesimpulan}

Menggunakan BMC pada 9 elemen termasuk ke dalam model perusahaan unbundling, PBN mengintegrasikan bisnis 3 inti yaitu, hubungan pelanggan, bisnis inovasi produk, dan bisnis insfrastruktur. Lingkungan internal yang mempengaruhi model bisnis PBN dipengaruhi oleh 4 aspek 1) produk yang dipengaruhi kualitas, kuantitas, bahan baku, proses produksi, SDM. 2) Customer Interface dipengaruhi jarak, kedekatan personal dan informasi media. 3) Infrastructur management dipengaruhi logistik, operasi, teknologi, HRM. 4) Aspek keuangan kemampuan modal perusahaan, hubungan baik dengan penanam modal, pengelola keuangan, harga jual produk, sistem akunting. 
Lingkungan ekternal yang paling mempengaruhi model bisnis PBN adalah Kekuatan makro ekonomi 25,76\%, Kekuatan pasar 25,21\%, Kekuatan industri 24,82\%, Tren kunci 24,21\%. Pengembangan model bisnis dengan perspektif BOS pada PBN diperioritaskan pada elemen value proposition yang menyebabkan penambahan komponen pada elemen-elemen lain dalam mendukung pengembangan BMC tersebut. Berdasarkan wawancara perusahaan juga sudah melakukan kajian untuk membuat produk jadi di perusahaan dan juga atas dorongan pelanggan menginginkan untuk membuat produk jadinya langsung di Indonesia (contract manufacture).

Saran

Penelitian "Analisis Model Bisnis pada PT. Pahala Bahari Nusantara dengan Menggunakan Pendekatan Bisnis Model Canvas" menekankan pada pengembangan strategik operasional perusahaan. Berdasarkan hasil dari berbagai analisis yang telah dilakukan banyak elemen perusahaan yang memiliki potensi untuk dikembangkan sehingga perlu dikaji/diteliti lebih mendalam. Beberapa saran penelitian/kajian lanjutan antara lain :

1. Kombinasi BMC dan BOS dapat menghasilkan strategi pengembangan model bisnis yang lebih dari satu atau sesuai dengan banyaknya elemen yang ingin dikembangkan sehingga perlu tambahan alat analisis yang dapat menghasilkan penilaian prioritas elemen yang akan dikembangkan, yang dalam penelitian ini tidak dapat dilakukan karena keterbatasan waktu.

2. Pendekatan BSC pada lingkungan internal bisa diperdalam lagi tidak terbatas pada penilaian faktor-faktornya saja tapi sebagai penilaian kinerja di perusahaan.

\section{DAFTAR PUSTAKA}

Cania L. 2014. The Impact of Strategic Human Resource Management on Organizational Performance. Economia Seria Management. Volume 17, Issue 2.

Craig JC, Grant RM. 1999. Manajemen Strategik. Jakarta (ID): Nediator.

David F. 2009. Strategic Management: concepts and case. New Jersey (US): Person Prentice Hall. 12nd edition

David FR. 2009. Manajemen Strategis: Konsep. Jakarta (ID): Salemba Empat. Dono Sunardi, Penerjemah. Edisi Kedua Belas.

Destiani DP.2014. Analisis strategi model bisnis kanvas pada PT. Angkasa Pura II untuk Bandara Internasional Soekarno Hatta [Tesis]. Bogor (ID): Institut Pertanian Bogor.

Frost \& Sullivan.2014. Independent Market Research on Selected Food Markets in Indonesia, China, India, Vietnam, and Myanmar.

Griffin, Jill. 2003. Customer Loyalty : Menumbuhkan dan Mempertahankan Pelanggan. Jakarta(ID): Airlangga.

Giesen, E. Berman, S. Bell, R. Blitz, A. 2007. Path To Succecc Three Ways to innovate Your Business Model. IBM Global Business Service. VOL. 35 NO. 6 2007, pp. 27-33.

Gilman, E. A. 2009. Minimizing Bycatch of Sensitive Species Groups in Marine Capture Fisheries: Lessons from Commercial Tuna Fisheries. Handbook of Marine Fisheries Conservation and Management. Oxford UniversityPress., 150-164.

Honet, De L dan Hey S.2011.A Grounded Theory on Business Model Structure of Google. International Journal of Electric Business Management, vol. 9, No 3, pp.231-242.

Jauzi, Ahmad, 2007. Arsitektur Strategik Taman Akuarium Air Tawar Taman Mini Indonesia Indah (TAAT-TMII). [Tesis]. Bogor (ID): Institur Pertanian Bogor. 
Kim WC, Mauborgne R. 2005. Blue Ocean Strategy: How to Create Uncontested Market Space Competiton Irrelevant. Boston (LN): Harvard Business School Press.

Lhator A. 1999. Society and corporate public relations-why the conflict?. Public Relations Quarterly 44(3), 33-40.

Moser HC. 2006. How to SWOT Southeast Asia. Manufacturing Engineering. 136(1):120.

Tim PPM Manajemen. 2012. Canvas model Business-Penerapan di Indonesia. Jakarta (ID): PPM

Osterwelder A dan Pigneur Y. 2010. Business Model Generation. New jersey (US): Jhon Wiley and Sons.

Ostelwelder A 2004. The Business Model Ontology A proposition is A Design Science Approach. Universite De Lausanne Ecole Des Haute EstudeCommerciales.

Pearce J, Robinson R. 2008. Manajemen Strategis: Formulasi, Implementasi dan pengendalian. Jakarta (ID): Salemba Empat.

Robinette, S. 2001. Emotional Marketting. Jakarta (ID). Mc. Grow Hill.

Salvatore D. 1997. Ekonomi Internasional. Edisi Kelima. Jakarta (ID): Erlangga.

Simatupang, T.M. (2016). Struktur dan Sistem Rantai Pendingin Ikan dalam Rangka Pengembangan Sistem Logistik Ikan Nasional (SLIN).

Silalahi KA. 2014. Analisis model bisnis pada divisi agribisnis Bank Rakyat Indonesia menggunakan pendekatan model kanvas [tesis]. Bogor (ID) : Institut Pertanian Bogor.

Solihah E. 2015. Arsitektur Strategik Berbasis Blue Economy di KNM Fish Farm-Sukabumi Jawa Barat. [tesis]. Bogor (ID): Institut Pertanian Bogor.

Stefan S dan Richard B. 2014. Analysis of business model. Journal of Competitiveness. 6(4): 1940

Valentin EK. 2001. SWOT analysis from a resource-based view. Journal of Marketing Theory and Practice. 9(2): 54-68.

Wheelen TL, Hunger JD. 2010. Strategic Management and Business Policy. Ed k-12. New Jersey (US) : Prentice Hall. 